\title{
Multiple Brain Abscesses by an Air Gun Shot: A Case Report
}

\section{Abscessos cerebrais múltiplos por tiro de arma de ar comprimido: relato de caso}

\author{
Mohammad Jamali ${ }^{1}$ Iman Ahrari ${ }^{1} \quad$ Keyvan Eghbal $^{1}$ Arash Saffarrian ${ }^{1}$ Abbas Rakhsha ${ }^{1}$ \\ Sulmaz Ghahramani \\ ${ }^{1}$ Department of Neurosurgery, Shiraz University of Medical Sciences, \\ Shiraz, Iran \\ 2 Health Policy Research Center, Institute of Health, Shiraz University \\ of Medical Sciences, Shiraz, Iran \\ Address for correspondence Sulmaz Ghahramani, MD, Health Policy \\ Research Center, Institute of Health, Shiraz University of Medical \\ Sciences, Zand Avenue, Building no 2, Eighth Floor, Shiraz, Iran \\ (e-mail: suli.ghahraman@gmail.com).
}

Arq Bras Neurocir 2021;40(4):e404-e407.

\section{Abstract \\ Keywords \\ - air gun shot \\ - brain abscess \\ - Shiraz \\ Resumo \\ Palavras-chave \\ - tiro de arma de ar comprimido \\ - abscesso cerebral \\ - Shiraz}

Introduction Low-velocity penetrating brain injury is not prevalent. In some conditions such as childhood, and with the penetration of a pellet in weak spots of skull, low-velocity penetrating brain injury is expected; however, high-velocity projectiles have also been reported as the cause of severe brain injuries. One of the complications of penetrating brain injury is infection, in which different types of microorganisms play a role. The Streptococcus genus is the leading cause of abscess formation in nontraumatic patients. Multiple brain abscesses are not common.

Case Presentation A 10-year-old boy with penetrating brain injury caused by an air gun pellet, who developed signs and symptoms of high intracranial pressure 18 days after the trauma. After the imaging scans and the detection of multiple brain abscesses and severe brain edema, prompt surgical intervention was performed for all three lesions in a single operation. The culture of a pus specimen was positive for Streptococcus species, and, with adequate antibiotic therapy, the patient was discharged from the hospital in good condition.

Conclusion Brain injury with air gun shot is not prevalent. The penetration of a low-velocity air gun pellet in weak points of the skull (such as the orbit, the squamous portion of the temporal bone, and the cranial suture), specially in children, can cause significant brain injuries.

Introdução A lesão cerebral penetrante de baixa velocidade não é prevalente. Em algumas condições, como na infância e com a penetração de bala em pontos fracos do crânio, é esperada lesão cerebral penetrante de baixa velocidade; no entanto, projéteis de alta velocidade também foram relatados como a causa de lesões cerebrais graves. Uma das complicações da lesão cerebral penetrante é a infecção, na qual diferentes tipos de microrganismos desempenham um papel. O gênero Streptococcus é a received

July 31,2020

accepted

March 9, 2021

published online

August 3, 2021
DOI https://doi.org/ $10.1055 / \mathrm{s}-0041-1731063$ ISSN $0103-5355$.

\footnotetext{
(c) 2021. Sociedade Brasileira de Neurocirurgia. All rights reserved. This is an open access article published by Thieme under the terms of the Creative Commons Attribution-NonDerivative-NonCommercial-License, permitting copying and reproduction so long as the original work is given appropriate credit. Contents may not be used for commercial purposes, or adapted, remixed, transformed or built upon. (https://creativecommons.org/ licenses/by-nc-nd/4.0/) Thieme Revinter Publicações Ltda., Rua do Matoso 170, Rio de Janeiro, RJ, CEP 20270-135, Brazil
} 
principal causa de formação de abscesso em pacientes não traumáticos. Abcessos cerebrais múltiplos não são comuns.

Relato do caso Um menino de dez anos com traumatismo cranioencefálico penetrante causado por projétil de arma de ar comprimido que desenvolveu sinais e sintomas de pressão intracraniana elevada 18 dias após o trauma. Após os exames de imagem e a deteç̧ão de múltiplos abscessos cerebrais e edema cerebral grave, a intervenção cirúrgica imediata foi realizada para todas as três lesões em uma única operação. A cultura de uma amostra de pus foi positiva para espécies de Streptococcus e, com antibioticoterapia adequada, o paciente recebeu alta hospitalar em boas condições.

Conclusão Lesões cerebrais por arma de ar comprimido não são comuns. A penetração de uma bala de arma de ar comprimido de baixa velocidade em pontos fracos do crânio (como a órbita, a porção escamosa do osso temporal e a sutura craniana), especialmente em crianças, pode causar lesões cerebrais significativas.

\section{Introduction}

Penetrating brain injury (PBI) is a less prevalent cause of traumatic brain injury, which carries a significantly poor prognosis. Both high-velocity (such as bullets and shell fragments) and low-velocity (shot gun and air gun pellets) projectiles may cause PBI. ${ }^{1}$

Various complications may occur in cases of PBI, such as vascular complications (including traumatic intracranial aneurysms, subarachnoid hemorrhage), traumatic cerebrospinal fluid leaks, and epilepsy, as well as infectious complications such as meningitis, cerebral abscess, and so on. The high-velocity gunshots are more deadly, but patients who suffer injuries from low-velocity projectiles require extra attention due to the potential complications.

Infectious complications account for $1 \%$ to $5 \%$ of cases of PBI in civilians, as compared with $4 \%$ to $11 \%$ of cases of PBI among military personnel. Retained contaminated foreign objects, skin, hair, and bone fragments in brain tissues are the main causes of infectious complications. A variety of complications, such as local wound infections, meningitis, ventriculitis, or cerebral abscess might also emerge. ${ }^{2-6}$

The origin of brain abscess are pericranial contiguous focus, hematogenous spread from a distant focus of infection, and direct inoculation of a pathogen after neurosurgical procedures or PBIs. $^{7}$

Brain abscess is associated with a variety of symptoms, such as headache, fever, irritability, confusion, muscle weakness, hemiparesis, neck rigidity, lethargy, diplopia, nausea, and vomiting.

Hereby, we present an interesting and rare case of a 10year old boy with PBI whose initital good condition deteriorated gradually with the onset of symptoms of progressive headache, vomiting, and confusion. Imaging studies revealed multiple brain abscesses.

\section{Case Presentation}

A 10-year-old boy with a PBI from a low-velocity air-rifle pellet from a moderate distance presented to a local hospital in Bandar-Abbas. His neurologic exam was unremarkable, with a Glasgow Coma Scale (GCS) of 15.

A non-contrast computed tomography (CT) scan of the head ( - Fig. 1 ) revealed a gunshot wound on the left frontal region, the path that the pellet took through the brain, and a retained pellet in the right frontal region by mechanism of ricochet injury. Regarding his intact neurologic exam and stable hemodynamic state, we decided to monitor his status with inpatient observation for a few days, and then outpatient follow-up.

Eighteen days later, he presented to our outpatient clinic with headache, nausea, vomiting, and confusion. The physical examination was positive for papilledema. A contrast CT scan of the brain revealed three ring-enhancing lesions in the frontal lobes bilaterally, which was suggestive of brain abscesses, and the pellet retained in the brain (-Fig. 2 ).

In an emergency operation, bilateral burr-hole craniotomy was performed, and all the three abscesses were aspirated and irrigated (-Fig. 3). Moreover, necrotic tissue and foreign bodies, such as hair and bone fragments, were removed. He was transferred to the neurosurgery intensive care unit (ICU). The following day, his condition was quite good.

Broad-spectrum antibiotics, including vancomycin, meropenem, and metronidazole, were prescribed after the

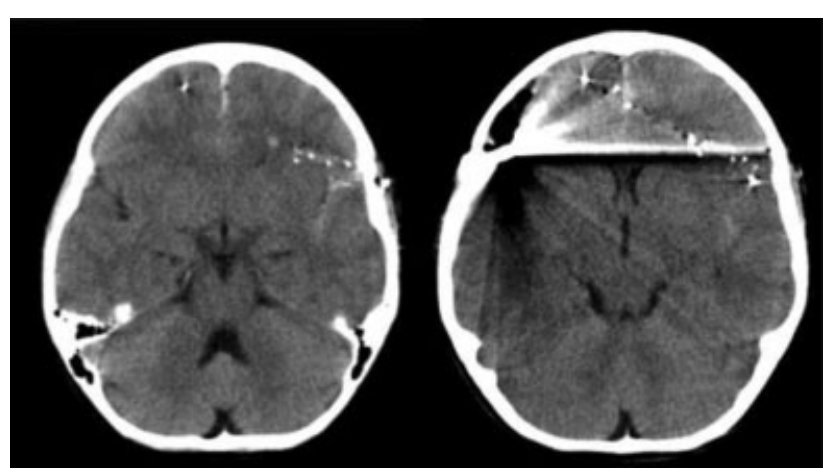

Fig. 1 Non-contrast brain CT three days following the trauma, showing multiple foreign bodies. No evidence of brain abscess is observed in these sections. 

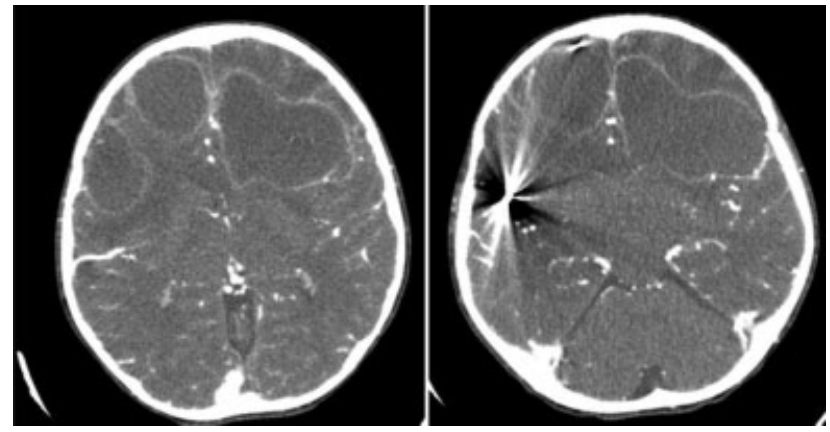

Fig. 2 Multiple brain abscess in axial cut of intravenous (IV) contrast brain CT scan 18 days after the trauma at the time of admission, with typical ring enhancement.

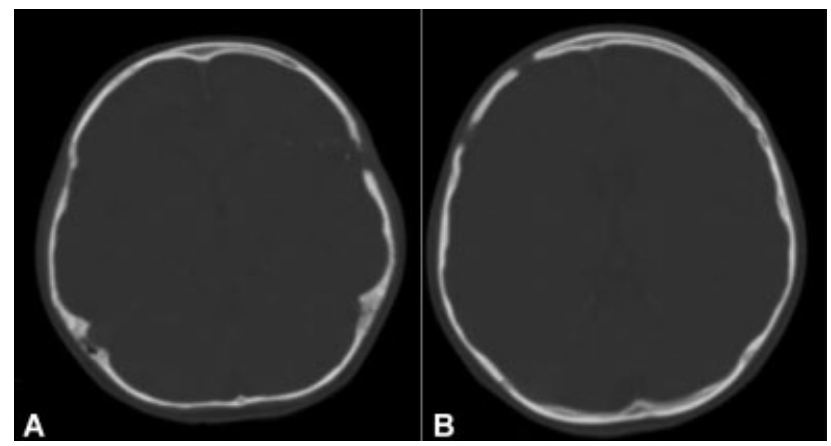

Fig. 3 (A) The point of entry of the projectile was extended for the removal of the foreign bodies and aspiration of the abscesses. (B) Two bur holes for the aspiration of the right-side abscesses.

consultation with an infectious-disease specialist due to the multiple abscesses and the patient condition, and were continued for 21 days. The abscess culture was positive for Streptococcus species five days after the antibiotic therapy was started. Because the patient responded to the antibiotics, they were not discontinued or changed.

He was discharged as he was in a good condition, with no sign of infection or neurological deficits. Three weeks later, he was revisited. His physical examination was unremarkable, with no signs or symptoms of neurological deficit. Follow-up imaging studies also revealed no recurrence of the abscesses (-Fig. 4).

\section{Discussion}

An air gun shot causing a low-velocity PBI is not prevalent. A tangential and careening injury is more expected to result from an air gun shot than other mechanisms of injury, such as penetration, perforation and ricochet. The points of entrance that could be expected for an air gun poallet are the weak spots of the skull, such as the orbit or the squamous portion of the temporal bone. Given the short diameter of the skull in children, penetration of the projectile is expected. ${ }^{8-10}$ In the case of our patient, the entry wound was on the coronal suture, a weak spot in children.

Although gram-positive pathogens such as Staphylococcus aureus and those of the genus Clostridium spp. are the main

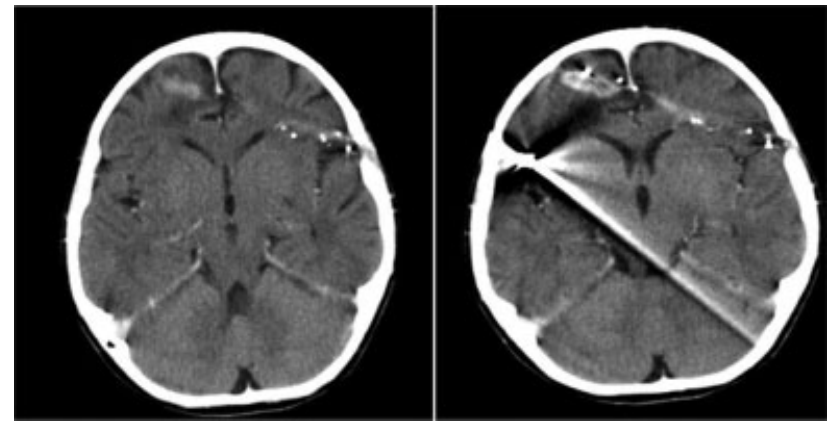

Fig. 4 Axial section of a non-contrast CT scan of the brain two weeks after admission, showing improvement of the brain abscesses and remnant foreign bodies.

causes of posttraumatic brain abscess, and gram-negative bacteria, such as those of the family Enterobacteriaceae, have also been isolated. ${ }^{11,12}$ Streptococcus species is a common cause of multiple brain abscesses with other causes rather than penetrating injury; ${ }^{13,14}$ however, it was the cause in the case herein reported.

Abscess after trauma usually forms within 2 to 4 weeks; in the present case it formed 18 days after the trauma. In some rare cases, abscess formation after trauma may take 2 to 3 months or even longer. ${ }^{15}$

Intracranial abscess is commonly observed in patients with penetrating head trauma and retained projectiles. ${ }^{7} \mathrm{We}$ removed necrotic tissue, hair, and bone fragments from the entry point of the pellet. The formation of multiple abscesses, with risk factors such as congenital heart disease, endocarditis, and immunodeficiency has been reported in some studies; however, multiple brain abscesses after aPBI is not prevalent. Prompt surgical intervention is needed for patients with large brain abscesses accompanied by clinical signs and symptoms of high intracranial pressure to achieve a better surgical result and find the microorganism. ${ }^{16}$ The laboratory evaluation is often normal in these patients, as it was in our case. ${ }^{17}$

The case herein reported highlights the significance of routine follow-up and complete evaluation in patients with retained intracranial projectiles. Although there were no neurological deficits or laboratory abnormalities, his unique presentation prompted further evaluation which revealed multiple lesions correlated to his symptoms.

\section{Conclusion}

Brain injury by an air gun shot is not prevalent. Penetration of a low-velocity air gun pellet in weak spots of the skull (such as the orbit, the squamous portion of the temporal bone, and the cranial suture), specially in children, can cause significant brain injuries.

\section{Statement of Ethics}

The patient's parents have given their written informed consent to publish the case (including the publication of images). 
Funding

This research did not receive any specific grant from funding agencies in the public, private, or not-for-profit sectors.

\section{Conflict of Interests}

The authors have no conflicts of interests to declare.

\section{Acknowledgments}

The authors would like to thank the patient and his family.

\section{References}

1 Kazim SF, Shamim MS, Tahir MZ, Enam SA, Waheed S. Management of penetrating brain injury. J Emerg Trauma Shock 2011;4 (03):395-402

2 Aarabi B. Traumatic aneurysms of brain due to high velocity missile head wounds. Neurosurgery 1988;22(6 Pt 1):1056-1063

3 Aarabi B. Causes of infections in penetrating head wounds in the Iran-Iraq War. Neurosurgery 1989;25(06):923-926

4 Aarabi B. Surgical outcome in 435 patients who sustained missile head wounds during the Iran-Iraq War. Neurosurgery 1990;27 (05):692-695, discussion 695

5 Aarabi B, Taghipour M, Alibaii E, Kamgarpour A, John CF. Central nervous system infections after military missile head wounds. Neurosurgery 1998;42(03):500-507, discussion 507-509

6 Aarabi B, Taghipour M, Haghnegahdar A, Farokhi M, Mobley L. Prognostic factors in the occurrence of posttraumatic epilepsy after penetrating head injury suffered during military service. Neurosurg Focus 2000;8(01):e1
7 Alvis Miranda H, Castellar-Leones SM, Elzain MA, Moscote-Salazar LR. Brain abscess: Current management. J Neurosci Rural Pract 2013;4(Suppl 1):S67-S81

8 Vakil MT, Singh AK. A review of penetrating brain trauma: epidemiology, pathophysiology, imaging assessment, complications, and treatment. Emerg Radiol 2017;24(03):301-309

9 Dalgıç A, Okay O, Ergüngör FM, Uçkun O, Nacar OA, Yıldırım AE. Brain injury due to air gun shot: report of three adult cases. Ulus Travma Acil Cerrahi Derg 2010;16(05):473-476

10 Gutiérrez-González R, Boto GR, Rivero-Garvía M, Pérez-Zamarrón A, Gómez G. Penetrating brain injury by drill bit. Clin Neurol Neurosurg 2008;110(02):207-210

11 Thomas SG, Moorthy RK, Rajshekhar V. Brain abscess in a nonpenetrating traumatic intracerebral hematoma: case report and review of literature. Neurol India 2009;57(01):73-75

12 Mahabeer Y, Khumalo A, Kiratu E, Mlisana K. Posttraumatic brain abscess caused by Aeromonas hydrophila. J Clin Microbiol 2014; 52(05):1796-1797

13 Kratimenos G, Crockard HA. Multiple brain abscess: a review of fourteen cases. Br J Neurosurg 1991;5(02):153-161

14 Hakan T, Ceran N, Erdem I, Berkman MZ, Göktaş P Bacterial brain abscesses: an evaluation of 96 cases. J Infect 2006;52(05):359-366

15 Savitri QM, Putri CP, Gunawan KJ, Hapsari DL, Sidharta I, Wicaksono P. Localized asymptomatic cerebellar abscess after penetrating brain injury by wooden foreign object with adequate antibiotics administration: A case report. Int J Surg Case Rep 2020;72:85-90

16 Brouwer MC, van de Beek D. Epidemiology, diagnosis, and treatment of brain abscesses. Curr Opin Infect Dis 2017;30(01):129-134

17 Milton J, Awuor V. A Unique Presentation of an Intracranial Abscess Secondary to Retained Projectile after Debridement with Dural Closure. Cureus 2017;9(06):e1328 